\title{
Analysis of Sinmap in Landslide Susceptibility Mapping of Coonoor Watershed, Nilgiris, India
}

\section{Subbarayan Saravanan ( $\nabla$ ssaravanan@nitt.edu )}

National Institute of Technology Tiruchirappalli https://orcid.org/0000-0003-4085-1195

Jacinth Jennifer Jesudasan

National Institute of Technology Tiruchirapalli

Leelambar Singh

National Institute of Technology Tiruchirapalli

Abijith Devanantham

National institute of technology Tiruchirapalli

Research

Keywords: Coonoor, GIS, Landslide Susceptibility map, SINMAP, Shallow landslide.

Posted Date: August 27th, 2020

DOI: https://doi.org/10.21203/rs.3.rs-63451/v1

License: (9) This work is licensed under a Creative Commons Attribution 4.0 International License. Read Full License 


\section{ANALYSIS OF SINMAP IN LANDSLIDE SUSCEPTIBILITY MAPPING OF COONOOR WATERSHED, NILGIRIS, INDIA}

ABSTRACT

Landslide susceptibility mapping is crucial for risk management in mountainous Nilgiris district, Tamil Nadu, India. In this study, the spatially distributed Stability INdex MAPping (SINMAP) model was used to develop a landslide susceptibility model for Coonoor watershed, which is based on a steady-state hydrologic model coupled with an infinite-slope stability equation. Shuttle Radar Topography Mission (SRTM) digital elevation model was utilized to compute the slope and other topographic parameters. In-situ data collection and laboratory tests were executed to estimate the hydro-geotechnical parameters. A detailed field study was conducted, and 35 samples were taken from the landslide locations to perform laboratory tests to find the geotechnical parameters. Also, an inventory landslide map was generated to evaluate the model performance. Statistical results of SINMAP show that, under the fully saturated condition, $58.96 \%$ of the region was found to be stable, $16.79 \%$ moderately stable, $8.72 \%$ quasi-stable and $15.24 \%$ unstable. The Area under the Curve (AUC) value of the predicted result is $72.3 \%$ which infer that the underlying predictors perform good in classifying the outcome. Thus, the considered parameters in the model have played its part well in the classification of the region based on its stability.

Keywords: Coonoor; GIS; Landslide Susceptibility map; SINMAP; Shallow landslide.

\section{INTRODUCTION}

Last few decades have faced worst diasaters, viz., floods, landslides, earthquakes, tsunamis and hurricanes, which prone a threat to human lives and property. Overall, landslides alone represents $9 \%$ of the natural diasaters which have happened worldwide during the 1990's and this trend is likely to carry on in upcoming decades with the increase in population and urbanization along with the drastic changes in the climate pattern (Schuster 1996).

The profound increase in the world's population leads to drastic climate change and disastrous events. Landslides are said to be one of the protuberant catastrophes around the world, most likely to occur in hilly terrain. However, landslides are claimed to be the natural processes that are responsible for the channel maintenance, landscape formation, evolution, and sediment supply; it also serves as a mechanism to release sediment from the slopes of hills to the stream and rivers (Cendrero \& Dramis 1996; Michel et al. 2014; Petley 2012). Among various geological risks, landslides instigate more human loss and damages that costs billions of dollars. Few measures to mitigate these losses include the generation of maps that implies the landslide susceptibility, danger and risk. Over latest years, geographical information systems (GIS) is gaining its potential for spatial data management, analysis and manipulation. The Indian hilly terrains in the Himalayas, North, East and the Western Ghats region are extremely susceptible to landslides (Mandal \& Mandal 2018). The occurrence of landslide is triggered by natural and human activities (Haigh \& Rawat 
2012). The causal factors of landslides may broadly be classified under geological causes, morphological causes and social causes (Mandal \& Maiti 2015). The strength of the terrain materials, their weathering property, presence of fractures and fissures, permeability and stiffness of the rocks fall under the geological causes. (Seshagiri Rao 2020). The tectonic and volcanic reflexes, erosion activity, type of vegetation, thawing and freezing activity are clubbed under the morphological causes. The excavation, construction, irrigation, deforestation, water leakage and mining from utilities are categorized under the human causes (Maina-Gichaba et al. 2013; Shit et al. 2015).

With the invention of remote sensing and GIS techniques, the disaster monitoring and management sectors have benefitted extensively. The mapping of landslide susceptibility zones has been done widely worldwide using numerous techniques and methodologies. The zone mapping demarcates the spatial extent, which is likely to landslide occurrence. The concerned region prone to landslides though triggered by external factors, the terrain properties and characteristics also influence the susceptibility of the region. Thereby, making it necessary to consider the triggering factors and causative parameters of the terrain.(Jennifer et al. 2020; Wang et al. 2014)

The characteristics of catchments and its sediment yield and its relationship with the occurrence of landslides have accelerated the need for study based on hydrological, physically-based and spatially-distributed models (Bathurst et al. 2005; Michel et al. 2014). The hydrological and stability models coupled with DEM in the GIS platform are utilized to calculate the factor of safety (FOS), which facilitates the analysis of various potential circumstances or rainfall events (Corominas \& Moya, 2008; Michel et al. 2014). There exist several stability models such as GEOtop-FS, SHALSTAB, CHASM, SHETRAN, SUSHI, TRIGRS, and SINMAP (Safaei et al. 2011). There are very few methods that adopt the terrain characteristics such as the geology of the bedrock, soil type, thickness and cohesive nature, landuse/ land cover, vegetation type including the drainage of the terrain and the precipitation in the region. Among these, the SINMAP (Stability INdex MAPping) (Pack et al. 1998) adopts probabilistic approach that utilizes the geomorphic, hydrological and geotechnical features. SINMAP is an extension designed for ArcView GIS SINMAP, which is extensively applied in assessing the shallow transitional land sliding phenomena influenced by the shallow groundwater convergence. The SINMAP approach is applicable to the shallow translational landsliding phenomena and is not functional in the case of analyzing deep-seated instability. The field information is essential for calibration, and the data required includes the soil and climate properties which are vastly inconstant in space and time. The precision of the output is greatly reliant on the digital elevation model (DEM) and the software relies on grid-based sata structures. The output stability indices are interpreted in terms of relative hazard, which could be assisted for reconnaissance-level and detailed mapping, given that the input data are reliable and precise (Pack et al. 1998). India, which is a disaster prone region with a history of significant landslide occurrence. A notable event is one which occurred in Novemeber 2009, when the landslide befell at over three hundred locations in the region causing severe damages to the people and society leaving nearly fifty people dead and hundreds of people homeless (Ganapathy et 
67 November, 2019. After 1978, this event has been declared as the major disaster in the district. Ooty, Coonoor and Kotagiri are the regions profoundly affected by landslides in the district.

The application of the SINMAP model over the region prone to shallow landslides triggered by rainfall has been implemented by various researchers in their study to predict the spatial distribution of the unstable zones (Zaitchik and Van 2003; Zaitchik et al. 2003; Calcaterra et al. 2004; Lan et al. 2004; Meisina and Scarabelli 2007).

\section{STUDY AREA DESCRIPTION}

The study area covers a part of Coonoor river watershed in the Nilgiris district, mountainous terrain in the NorthWestern part of Tamil Nadu, India. The Coonoor watershed has a catchment area of $45.4 \mathrm{~km}^{2}$ and extends from latitude $11^{\circ} 2000 \mathrm{~N}$ to $11^{\circ} 2800 \mathrm{~N}$ and longitude $76^{\circ} 4005 \mathrm{E}$ to $76^{\circ} 4940 \mathrm{E}$ in the Nilgiris district (Fig 1). The watershed predominantly consists of forest (38.7\%), tea estates (14.7\%), cropland (11\%), settlement (19.2\%), and scrub land (29.2\%) (Saravanan et al. 2019). The elevation of the terrain ranges from 1557 to 2638 meters above the sea level. The basin has four distinct seasons, South-West monsoon (SW) and North-East monsoon (NE) ) from June to September, and October to December respectively, and the winter and summer season from January to February from March to May respectively. The average annual rainfall ranges from 1100 to $1600 \mathrm{~mm} / \mathrm{year}$, while most of the precipitation is predominant during the NE monsoon period. The depth of the soil usually varies from one to three feet and that of the sub-soil from 3 to $5 \mathrm{~m}$. The soil gets saturated even during the low-intensity rains and water flush through the fissures rapidly. The geology is represented by the Charnickite group which comprises of two-pyroxene granulite, charnockite, banded quartz-magnetite quartzite and thin pink quartzo-felspathic granulite outcropping or covered by forest-cum-grassland (Guru et al., 2017). The rocks are metamorphic in nature and various geomorphic features comprised in this region are debris slope, denudational hill, denudational slope and plateau. The economy of this region depends highly on the cultivation of tea plantations, The temperature of the district ranges between $18^{\circ} \mathrm{C}$ to $28^{\circ} \mathrm{C}$ during summer and between $0^{\circ} \mathrm{C}$ to $16^{\circ} \mathrm{C}$ during winter. The viability of occurrence of landslides are abundant in the area, and mostly shallow translational debris slides and flows in cut slopes occur at the transportation routes (Jaiswal and Van Westen 2009).

\section{<Figure 1 Study area map of Coonoor watershed, Nilgiris, India>}

<Table 1 Materials and data source of the study area>

\section{HISTORY OF LANDSLIDES IN COONOOR WATERSHED}

As per the inventory record for the period 1987-2007, 1040 landslides have been compiled, which were triggered on 116 different periods. Out of 1040, 643 (62\%) landslides were found to have been occurred at the railway slip regions, 259 (24\%) along the railroads, and the remaining 132 happened to have occurred at various other zones. In the study area, shallow translational debris slides are predominant. Moreover, the inventory reports claim that there had been a 
frequent occurrence of landslides annually in the region (except 1995) with an average rate of 20 landslides per year. The first tragedy due to the monsoon occurred on November $4^{\text {th }}, 1978$, in which scores of people lost their lives due to drowning, house collapse and landslides. Coonoor and Kotagiri region was profoundly affected due to this event. In the year 1979, heavy rain for 10 days was prevalent in November, which triggered landslides at various locations. Later, a massive landslide occurred on October 25, 1990; it buried 35 people alive in the Geddhai region. A cloudburst induced another landslide event on $11^{\text {th }}$ November 1993 which washed away a long stretch of highway between Coonoor and Mettupalayam and there were human losses too. Following this event, on $11^{\text {th }}$ December 1998, a massive boulder fell on the same highway which blocked the road for several days. Later in December 2001, intense rainfall caused two major landslides in the highways itself. On November 14, 2006 occurrence of continuous rainfall triggered several landslides in the Nilgiris district. The major landslide in the recent past occurred in November 2009, which killed numerous lives and properties of the residents and government. Nearly 60 landslides have been found to have occurred in the Kattabettu and Coonoor road, and a $60 \mathrm{~m}$ pit was found along the roadside near Aravenu. This desperate event caused major damages to the utilities and the Coonoor region had no power supply for five days $\left(7^{\text {th }}\right.$ to $11^{\text {th }}$ of Nov, 2009) and the roads were also blocked due to damages, putting the people under greater struggle and distress. This substantial calamitous event is considered in the present study to map the landslide susceptible zones in the Coonoor watershed region. Figure 2 depicts the hourly and cumulative rainfall of three days (8.11.2009 to 10.11.2009) on Coonoor watershed region.

\section{<Figure 2 Hourly and cumulative rainfall intensity of Coonoor watershed on 8 - 10 November, 2009>}

\section{METHODOLOGY}

The infinite-slope stability model is the foundation of the SINMAP model. Here, the gravity and friction components that aid in restoration of the plane are considered to be balanced on a failure plane with an addition to the negligence to edge effects (Hammond et al. 1992; Montgomery \& Dietrich 1994). The specific catchment area, its topographic slope and hydrologic wetness parameters contributes in the assessment of terrain stability of the model (Pack et al.

122 1998). The increase in the moisture of the soil is directly proportional to its pore pressure thereby causing a reduction

123 in the effective normal stress, thereby shear strength. This study assumes hydrologic steady state in the computation of pore water pressure. The parameters involved in the model such as topographic variable are derived from the DEM and the other hydrological input parameters are provided in terms of upper and lower bounds due to their uncertainty. The stability index, which is obtained as the primary output from the model is defined such that the probability of a location being stable is assumed when the parameters are uniformly distributed over uncertainty ranges. However, the instability arises when the combined parametric values lie within the bounds of uncertainty and variability (Pack et al. 1998).

The primary data requirements include the hydrological data, geotechnical data, geographical data and field data for validation of the results. The secondary data retrieved from the primary ones are fed into the model; they include, rainfall and hydrological conductivity from hydrological data, cohesion and angle of internal friction from geotechnical data and DEM from geographical data. The topographic wetness index which is reliant on hydrologic 
134 and geomorphologic condition is considered as a vital parameter in the evalution of slope stability. These parameters

150 Where,

$151 F S-$ Factor of Safety

$152 c_{l}$-effective cohesion $\left(\mathrm{KN} / \mathrm{m}^{3}\right)$

153

154

155

156

157

158

$C_{s}-$ cohesion in soil

$C_{r}-$ cohesion in root

$\gamma_{w}$ - unit weight of soil $\left(\mathrm{KN} / \mathrm{m}^{3}\right)$

$Z_{w}$ - underground water level

$Z$ - soil depth from ground surface

$\gamma$ - unit weight of water $\left(\operatorname{ton} / \mathrm{m}^{3}\right)$

$\theta$ - slope of the terrain $\left(^{\circ}\right)$

$\phi$-internal friction angle $\left(^{\circ}\right)$

161 The steady-state hydrological model (Eq. (4)) is used to estimate soil saturation, assuming that the maximum value of $162 h / z$ is equal to 1 . Then, if the value is $>1$, the overland flow is formed.

$$
m=\frac{Z_{w}}{Z}
$$




$$
W=\frac{h}{z}=\min \left(\frac{q \cdot a}{T \cdot b \cdot \sin \theta}, 1\right)
$$

164 Where,

$165 W$ - saturation index (wetness)

$166 q$-effective precipitation

$167 T$ - landslide soil transmissivity $\left(\mathrm{m}^{2} / \mathrm{h}\right)$

$168 a$-specific catchment area or contributing area

169 The $\mathrm{q} / \mathrm{T}$ rate determines the relative wetness in terms of uniform recharge state in relation to soil capability in drain water; moreover, it represents the saturation state of landslide rock mass or soil. The term 'steady state' in the model does not represent long term average recharge, rather it denotes the rate of effective recharge which triggers landslides

172 during the critical period (Pack et al. 1998).

173 The value of saturation $(W)$ ranges between 0 and 1 , where 1 denotes complete saturation. Based on the variability in 174 slope and wetness $(W)$ the grid cells were classified into four categories as follows:

175 Class A - moist rolling terrain $\left(\theta<30^{\circ}, W<0.5\right)$

176 Class B - wet rolling terrain $\left(\theta<30^{\circ}, W \geq 0.5\right)$

177 Class $\mathrm{C}$ - moist steep terrain $\left(\theta \geq 30^{\circ}, W<0.5\right)$

178 Class D - wet steep terrain $\left(\theta \geq 30^{\circ}, W \geq 0.5\right)$

$17930^{\circ}$ is opted as a cut-off to distinguish the steepness of terrain according to the FAO definition of steep lands.

In SINMAP, a probabilistic approach was applied to solve the uncertainty problem.

$$
\begin{gathered}
S I=\operatorname{Pr} o b(F S>1) \\
S I=F S \min =\frac{c_{1}+\cos \theta\left[1-\min \left(x_{2} \frac{a}{b \cdot \sin \theta}, 1\right) \cdot r\right] \cdot t_{1}}{\sin \theta}
\end{gathered}
$$

183

184

185

Denoting $c_{l}=C_{r}+C_{s}$ and $\tan \phi=t_{l}$, the worst combinations of parameters for landslide stability can be defined by the minimum value of cohesion and internal friction angle $\left(C_{I m i n}\right.$ and $\left.t_{\min }\right)$ together with the maximum value of precipitation $\left(X_{\max }\right)$. The region which holds the FS less than 1 are prone to failure in slope and it is said to be related to the uncertainty of spatial and temporal variation in parameters. FS equals 1 suggests the condition of slope to be in the edge between stability and unstability. However, the FS values presides between 0 and 1 (i.e), most unstable and least unstable respectively. The SI values tends to get greater than 1 when the most conservative model parameters results in stability.

The methodology adopted by SINMAP is shown in Figure 3 and stability classes are shown in Table 1 . The table 1 defines the broad classes of stability. The selections of these breakpoints $(1.5,1.25,10.5,0.0)$ are said to be subjective. 
The stability index for these cases implies the factor of safety, which is determined from the combination of the parameters that induces instability (Pack et al., 1998).

\section{<Table 2 Stability Class Definitions>}

\subsection{Collection of field data}

The identified landslides were recorded using GRAMIN GPS locator and were mapped. A total of 35 locations were identified and they comprise of mosty shallow landslides which shows a progressive nature. The soil samples were collected on $6^{\text {th }}$ January 2010 from all the landslide scars; the runout length breadth and volume of the landslide locations were also measured. The samples were collected from sites with correspondence to the range of soil and land-use types in the study region. However, topographical parameters and landslide history were not accounted in site selection of sample collection.

\section{<Figure 4 Photographs of landslide scarps in the Coonoor region>}

\section{RESULTS AND DISCUSSION}

The stability index map was derived from the SINMAP model using the DEM and landslide inventory data as inputs. The SINMAP model adopted to study the stability of the Coonoor watershed region incorporates input data such as the topographic slope, the soil properties, soil depth, water table parameters and time-varying rainfall intensity. The slope of the terrain was computed from the using SRTM 30 m DEM. Along with the slope, the morphometric parameters such as flow direction and flow accumulation were also computed for the determination of saturation.

The region was assigned with a uniform geotechnical properties due to the small size of the catchment area, where the region is predominantly covered by loamy soil with a negligible cohesion. The soil friction angle ranges from $27^{\circ}$ to $30^{\circ}$, as obtained from the shear stress tests conducted in the lab. Soil unit weight ranges from 17.45 to $19.4 \mathrm{kN} / \mathrm{m}^{3}$ and the soil depth is found to be varied from 1-10m. Root cohesion values at different depths have been adopted from previous literature (Bischetti 2009). Average value of the geotechnical parameters has been applied for the initial simulation. The collected soil samples from the study region, its type and properties have been discussed in Table 2 .

Figure 5 depicts the DEM, flow direction, contributing area and slope maps. According to the model description, the variables to be considered include $a, h, r, C, T / q$. The specific catchment area $a$ and the slope angle $h$ are derived from DEM. The samples collected from the landslide locations are tested and the corresponding geotechnical parameter database shown in table 2 and 3. The effective rainfall $q$ was evaluated from the real-time rainfall data.

<Figure 5 (a) DEM, (b) Flow Direction, (c) Contributing area, (d) Slope map of Coonoor watershed>

Wetness index gives an idea of slope failure under the influence of groundwater being half saturated. The significant factor of the landslide equation is the ratio between the underground water level and the soil depth, $m$. The value of $m$ is 0 when the underground water level is none, and 1 when it is fully saturated. In general, the simulations were 
performed, while the parameters are changed relative to the thickness of the soil and T/R ratios for better susceptibility mapping. However, the November 2009 rainstorm existed for five days, which left the region fully saturated. Figure 6 portrays the saturation index map of the Coonoor watershed region.

\section{<Table 3 Parametric description of the soil samples>}

\section{<Table 4 Parameters' range used in parameter estimation>}

\section{<Figure 6 Saturation index map of Coonoor watershed>}

Table 4 indicates the classification details of the Coonoor watershed based on its stability. The results are shown in table 4 and stability map is shown in figure 7 in which, every pixel in the investigation area is assigned with a specific stability index (SI) value. The SI values more than zero, yields low potential slide susceptibility (Pack et al. 2001; Wawer and Nowocien 2003). The evaluation of stability index shows that the unconditionally unstable category characterizes approximately $75.0 \%$ of the observed landslide scars. Under the fully saturated condition, $58.96 \%$ of the region was found to be stable, $16.79 \%$ moderately stable, $8.72 \%$ quasi-stable and $15.24 \%$ unstable. Figure 7 shows the distributed stability index with the identified landslide location. Out of sixteen landslides measured in the study area, twelve landslides were identified in unstable area one in quasi-stable, one from moderately stable and two from stable area. The results obtained in the present work depicts that there exists a higher density of slides at the region with high probability of unstability. However, its also evident that at higher altitudes where the saturation level is at minimum the probability of slide occurrence is considerably lower whilst the occurrence of slide in these region are contributed by the slope gradient.

\section{<Table 5 Stability index classification for Coonoor watershed>}

\section{<Figure 7 Stability index map of Coonoor watershed>}

The slope seems to play a considerable role in the stability of the region; thereby an enhanced approach has been adopted to classify the region based on its slope factor relative to the prominent stability index in it. Table 5 portrays the classification of the slopes based on their stability concerning the Coonoor watershed region. It has shown evidence that the very steep slopes have been highly unstable though steep slope and moderately slope areas are quasistable and unstable. A portion of flat land also falls under the highly unstable region, which may be due to the influence of other influencing factors and soil parameters. Moreover, this classification of the stability of slopes has been categorized based on its behaviour at the dry condition. At wet condition, there exist high feasibility of the variation in the behaviour of the slopes.

\section{<Table 6 Area in percentage for different stability classes for different slope types under dry condition>}

It is essential to discuss the results based on the land use/land cover of the study area. The Coonoor watershed region is highly comprised of tea plantations, which cover $48.06 \%$ of the region followed by dense forest $(29.10 \%)$, wasteland $(13.74 \%)$, cultivation land (5\%) and built-up area (4.09\%). Table 6 depicts the stability classification of the study 
region based on its land use/ land cover. The wastelands are found to be highly unstable, followed by the cultivation

257 land while the dense forest region is highly stable.

258 The comparison between figure 6 and 7 implies he effect of saturation on soil stability. The saturation ratio $(\mathrm{m})$ has

259 played a considerable role in defining the stability of slope. From the results, it is evident that higher the saturation

260 index lower the staibility of the region. The model emphasizes the account of saturation index in assessing the 261 staibility.

<Table 7 Area in the percentage of stability classes for different land use/land cover types>

263 The calibration of the model is carried out by the comparison between the landslide scars mapped from the field with

264 the simulated output from the model. Better calibration performance is attained with more positive comparisons where

265 more coincidences are obtained. The assessment of model efficiency is also based on the observed instability area and

266 the number of landslide points falling on that area. Further, the resultant susceptibility map was validated using the

267 Receiver Operating Characteristic curve (Figure 8). It has been adopted to validate the predictive index, which is no

268 better than pure chance in forecasting an event. The obtained AUC value is $72.3 \%$, which infer that the model has

269 performed good in classifying the outcome.

\section{<Figure 8 Receiver Operating Characteristic Curve>}

\section{CONCLUSIONS}

272 The landslide susceptibility mapping has been carried out at various region adopting numerous analytical techniques.

273 Stability Index MAPping (SINMAP) analysis figures out the probable unstable region susceptible to landslide. In 274 particular is delieates the swales where many landslides originate (Park et al. 1998). The recent disastrous event based 275 on landslides in the Nilgiris district has been taken into account for the current study. The November 2009 intense rainfall has caused numerous landslides in the Coonoor watershed region, which were investigated to identify and measure the scarps, damages and the intensity of the disaster. The stability indexes obtained from the model classifies

278 the study region based on its stability factor. These stability indices depend upon various topographical, morphological 279 and geotechnical parameters. These parameters and their characteristics influence the stability of the terrain at the onset of precipitation condition. The SINMAP model is an efficient tool to classify the small region based on its stability. However, the incorporation of aerial photo analysis along with field mapping techniques would increase the performance of the model. In this present research, the resultant stability index map shows that the unconditionally unstable category have $75.0 \%$ of the observed landslide scars. The resultant ouput SI map could be utilized by district administrators and land developers to ascertain decision based on the risk of the terrain. 
Stability INdex MAPping (SINMAP), Shuttle Radar Topography Mission (SRTM), Area under the Curve (AUC), Geographical information systems (GIS), Factor of safety (FOS), Digital elevation model (DEM), Specific stability index (SI).

\section{AVAILABILITY OF DATA AND MATERIALS}

Landslide inventory of the study area and other data can be shared upon request.

\section{REFERENCES}

Bathurst, J. C., Moretti, G., El-Hames, A., Moaven-Hashemi, A., \& Burton, A. (2005). Scenario modelling of basinscale, shallow landslide sediment yield, Valsassina, Italian Southern Alps. Natural Hazards and Earth System Science, 5(2), 189-202. doi:10.5194/nhess-5-189-2005

Bischetti, G. B., Chiaradia, E. A., Epis, T., \& Morlotti, E. (2009). Root cohesion of forest species in the Italian Alps. Plant and Soil, 324(1-2), 71-89. doi:10.1007/s11104-009-9941-0

Calcaterra, D., Bruno, D., Parise, M., Silvestri, F., Critelli, S., \& Capparelli, G. (2004). Effects of weathering on slope instability in gneissic rocks at Luzzi (Calabria, Italy). Landslides: Evaluation and Stabilization/Glissement de Terrain: Evaluation et Stabilisation, Set of 2 Volumes, 1233-1239. doi:10.1201/b16816-179

Cendrero, A., \& Dramis, F. (1996). The contribution of landslides to landscape evolution in Europe. Geomorphology, 15(3-4), 191-211. doi:10.1016/0169-555x(95)00070-1

Corominas, J., \& Moya, J. (2008). A review of assessing landslide frequency for hazard zoning purposes. Engineering Geology, 102(3-4), 193-213. doi:10.1016/j.enggeo.2008.03.018

Ganapathy, G. P., Mahendran, K., \& Sekar, S. K. (2010). Need and urgency of landslide risk planning for Nilgiri District, Tamil Nadu State, India. International Journal of Geomatics and Geosciences, 1(1), 29-40.

Guru, B., Veerappan, R., Sangma, F., \& Bera, S. (2017). Comparison of probabilistic and expert-based models in landslide susceptibility zonation mapping in part of Nilgiri District, Tamil Nadu, India. Spatial Information Research, 25(6), 757-768. doi:10.1007/s41324-017-0143-1

Haigh, M., \& Rawat, J. S. (2012). Landslide Disasters: Seeking Causes - A Case Study from Uttarakhand, India. Management of Mountain Watersheds, 218-253. doi:10.1007/978-94-007-2476-1_18

Hammond, C., Hall, D., Miller, S., \& Swetik, P. (1992). Level I Stability Analysis (LISA) Documentation for Version 2.0 (General technical Report INT-285). US Forest Service Intermountain Research Station, Ogden, UT.

Jaiswal, P., \& van Westen, C. J. (2009). Estimating temporal probability for landslide initiation along transportation 
routes based on rainfall thresholds. Geomorphology, 112(1-2), 96-105. doi:10.1016/j.geomorph.2009.05.008

316

317

318

319

320

321

322

323

324

325

326

327

328

329

330

331

332

333

334

335

336

Jennifer, J. J., Saravanan, S., \& Pradhan, B. (2020). Persistent Scatterer Interferometry in the Post-Event Monitoring of the Idukki Landslides. Geocarto International, 1-15. doi:10.1080/10106049.2020.1778101

Lan, H. X., Zhou, C. H., Wang, L. J., Zhang, H. Y., \& Li, R. H. (2004). Landslide hazard spatial analysis and prediction using GIS in the Xiaojiang watershed, Yunnan, China. Engineering Geology, 76(1-2), 109-128. doi:10.1016/j.enggeo.2004.06.009

Maina-Gichaba, C., Kipseba, E. K., \& Masibo, M. (2013). Overview of Landslide Occurrences in Kenya. Kenya: A Natural Outlook - Geo-Environmental Resources and Hazards, 293-314. doi:10.1016/b978-0-444-59559$1.00020-7$

Mandal, S., \& Maiti, R. (2015). Semi-quantitative Approaches for Landslide Assessment and Prediction. doi:10.1007/978-981-287-146-6

Mandal, S., \& Mandal, K. (2018). Modeling and mapping landslide susceptibility zones using GIS based multivariate binary logistic regression (LR) model in the Rorachu river basin of eastern Sikkim Himalaya, India. Modeling Earth Systems and Environment, 4(1), 69-88. doi:10.1007/s40808-018-0426-0

Meisina, C., \& Scarabelli, S. (2007). A comparative analysis of terrain stability models for predicting shallow landslides in colluvial soils. Geomorphology, 87(3), 207-223. doi:10.1016/j.geomorph.2006.03.039

Michel, G. P., Kobiyama, M., \& Goerl, R. F. (2014). Comparative analysis of SHALSTAB and SINMAP for landslide susceptibility mapping in the Cunha River basin, southern Brazil. Journal of Soils and Sediments, 14(7), 12661277. doi:10.1007/s11368-014-0886-4

Montgomery, D. R., \& Dietrich, W. E. (1994). A physically based model for the topographic control on shallow landsliding. Water Resources Research, 30(4), 1153-1171. doi:10.1029/93wr02979

Pack, R. T., Tarboton, D. G., \& Goodwin, C. N. (1998). Terrain stability mapping with SINMAP, technical description and users guide for version 1.00 .

Pack, R.T., Tarboton, D.G., Goodwin, C.N., 2001, Assessing terrain stability in a GIS using SINMAP: Presented at the 15th Annual GIS Conference, GIS 2001, February 19- 22, Vancouver, B.C., Canada, 9 p

Petley, D. (2012). Global patterns of loss of life from landslides. Geology, 40(10), 927-930. doi:10.1130/g33217.1

Safaei, M., Omar, H., Huat, B. K., Yousof, Z. B., \& Ghiasi, V. (2011). Deterministic rainfall induced landslide approaches, advantage and limitation. Electronic Journal of Geotechnical Engineering, 16, 1619-1650. 
Saravanan, S., Jennifer Jacinth, J., Singh, L., Saranya, T., \& Sivaranjani, S. (2018). Impact of Land-use Change on Soil Erosion in the Coonoor Watershed, Nilgiris Mountain Range, Tamil Nadu, India. Advances in Science, Technology \& Innovation, 109-111. doi:10.1007/978-3-030-01440-7_26

Seshagiri Rao, K. (2020). Characterization, Modelling and Engineering of Rocks and Rockmasses. Indian Geotechnical Journal. doi:10.1007/s40098-020-00414-6

Shit, P. K., Paira, R., Bhunia, G., \& Maiti, R. (2015). Modeling of potential gully erosion hazard using geo-spatial technology at Garbheta block, West Bengal in India. Modeling Earth Systems and Environment, 1(1-2), 1-16. https://doi.org/10.1007/s40808-015-0001-x

Safaei M, Omar H, Huat BK, et al (2011) Deterministic rainfall induced landslide approaches, advantage and limitation. Electron J Geotech Eng 16:1619-1650

Schuster RL, Kockelman WJ (1996) Principles of landslide hazard reduction. In: Turner AK, Shuster RL (eds) "Landslides: investigation and mitigation". Transportation Research Board - National Research Council, Special Report 247, pp 91-105

Uvaraj, S., \& Neelakantan, R. (2018). Fuzzy logic approach for landslide hazard zonation mapping using GIS: a case study of Nilgiris. Modeling Earth Systems and Environment, 4(2), 685-698. doi:10.1007/s40808-018-0447-8

Wang, M., Liu, M., Yang, S., \& Shi, P. (2014). Incorporating Triggering and Environmental Factors in the Analysis of Earthquake-Induced Landslide Hazards. International Journal of Disaster Risk Science, 5(2), 125-135. doi:10.1007/s13753-014-0020-7

Wawer, R., \& Nowocień, E. (2003). Application of SINMAP terrain stability model to Grodarz stream watershed. Electron J Pol Agric Univ, 6(1), 03.

Zaitchik, B.F., Van Es, H.M. (2003), Applying a GIS slope-stability model to site-specific landslide prevention in Honduras. Journal of Soil and Water Conservation 58(1), pp. 45-53.

Zaitchik, B. F., van Es, H. M., \& Sullivan, P. J. (2003). Modeling Slope Stability in Honduras. Soil Science Society of America Journal, 67(1), 268-278. doi:10.2136/sssaj2003.2680.

\section{ACKNOWLEDGMENTS}

Not applicable

\section{Authors' contributors}


370 Subbarayan Saravanan: Conceptualization, Methodology, Supervision, Formal analysis. All authors participated in

371 the field investigation, result interpretation and drafted the manuscript. All authors have read and approved the final

372 manuscript.

\section{$373 \quad$ Funding}

374 Not applicable

375 Author information

376 Affiliations:

377 Department of Civil Engineering, National Institute of Technology, Tiruchirappalli, India

378 Corresponding Author:

379 Correspondence to Subbarayan Saravanan

380 Ethics declarations

381 Competing interests:

382 The authors declare that they have no competing interests. 
Figures
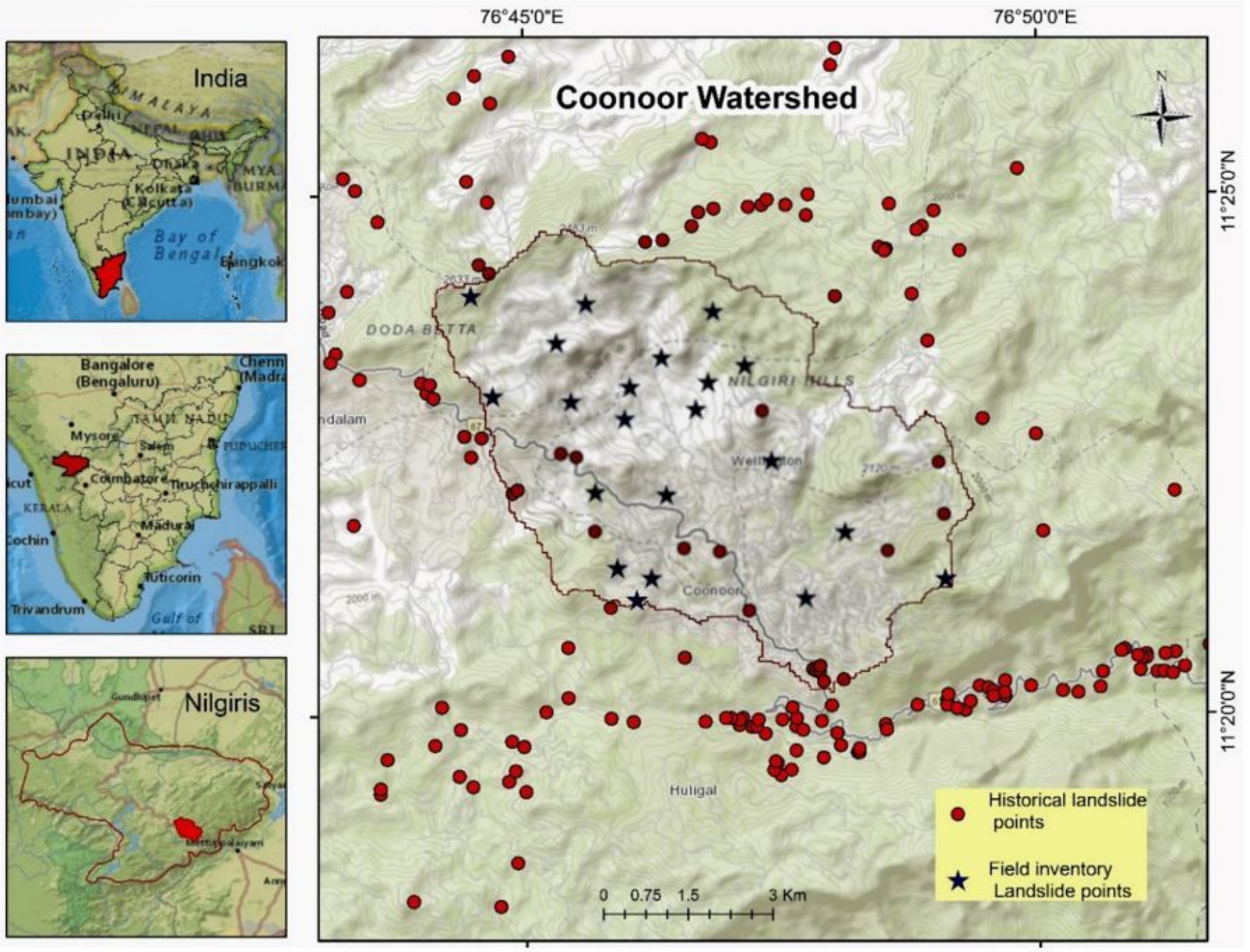

Figure 1

Study area map of Coonoor watershed, Nilgiris, India 


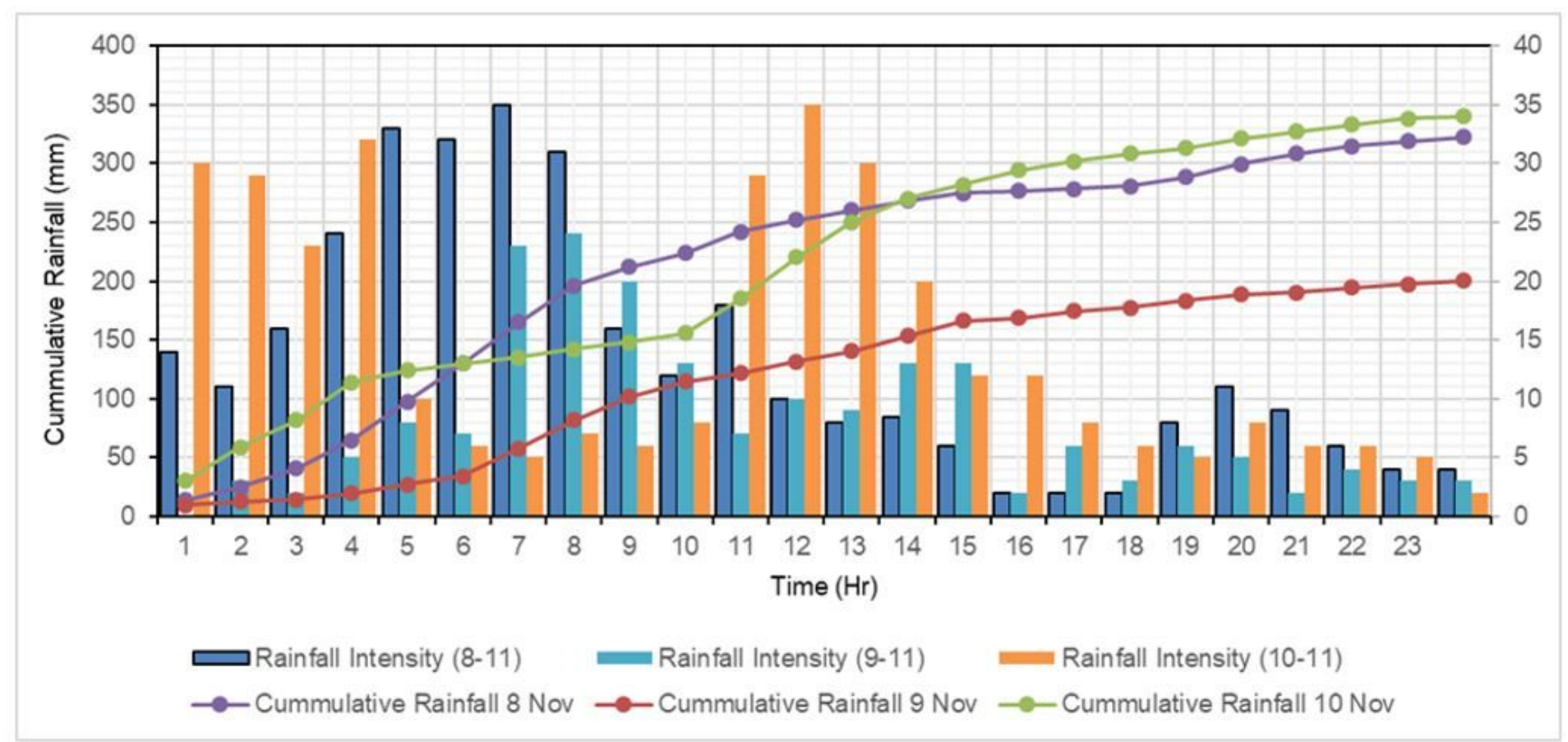

Figure 2

Hourly and cumulative rainfall intensity of Coonoor watershed on 8 - 10 November, 2009 


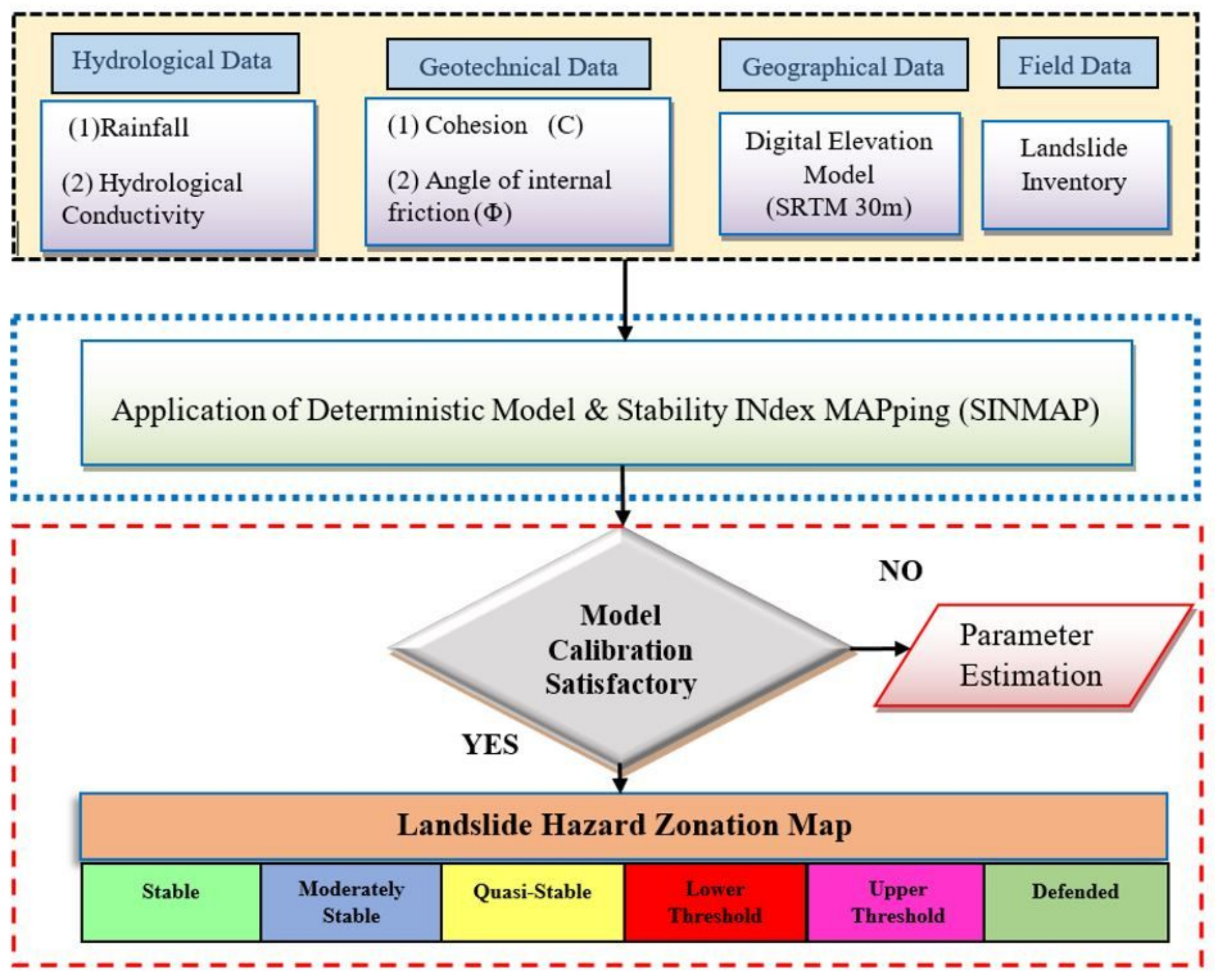

Figure 3

Methodology flow chart 

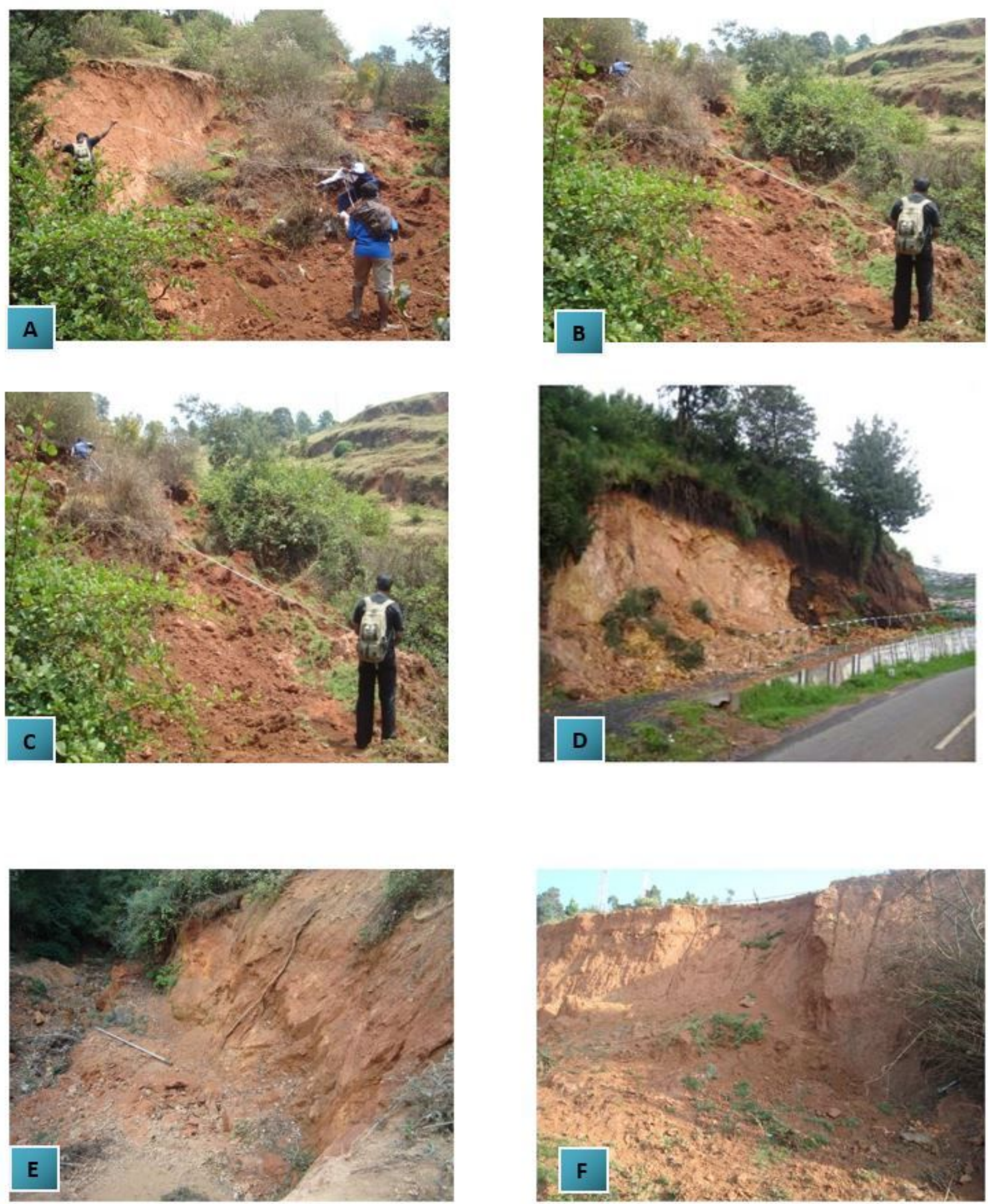

Figure 4

Photographs of landslide scarps in the Coonoor region 


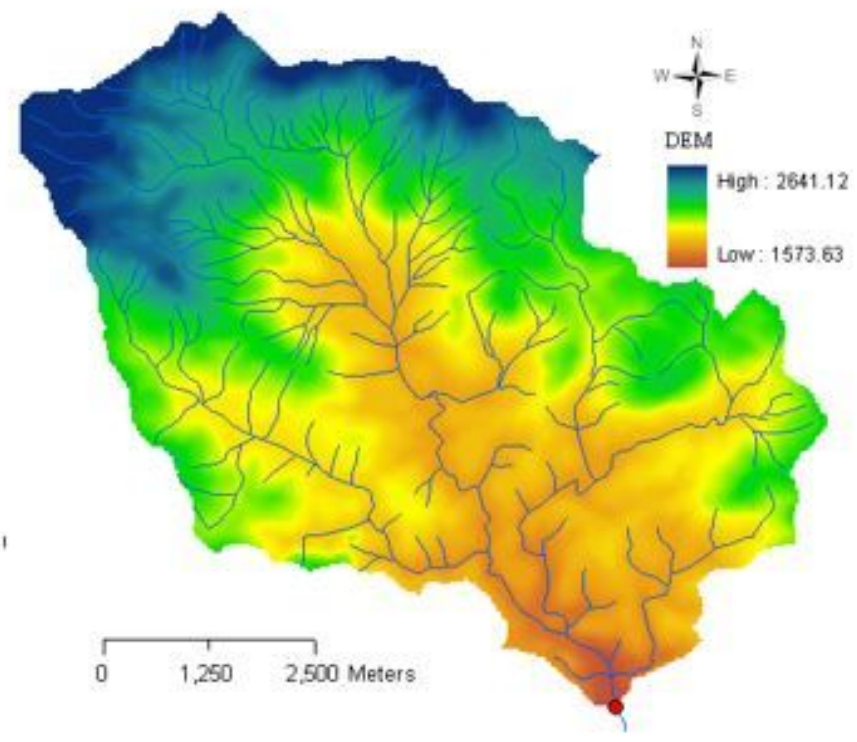

(a)

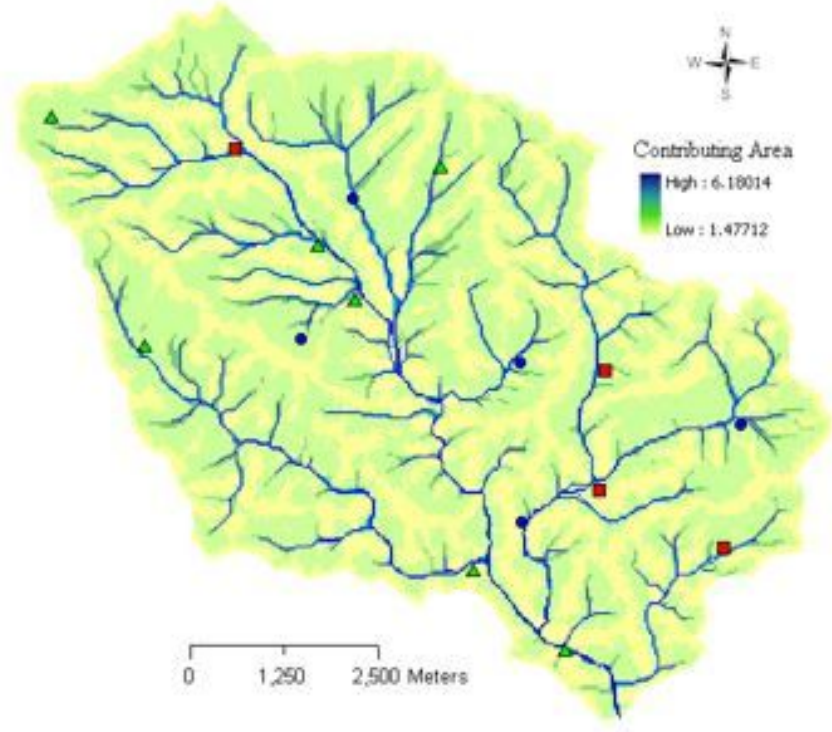

(c)

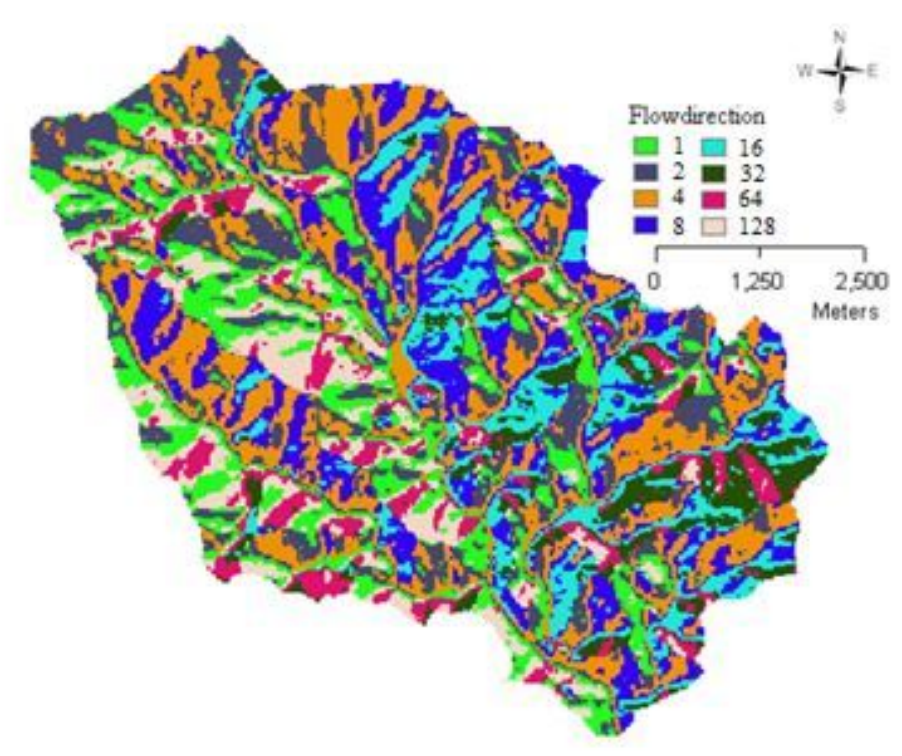

(b)

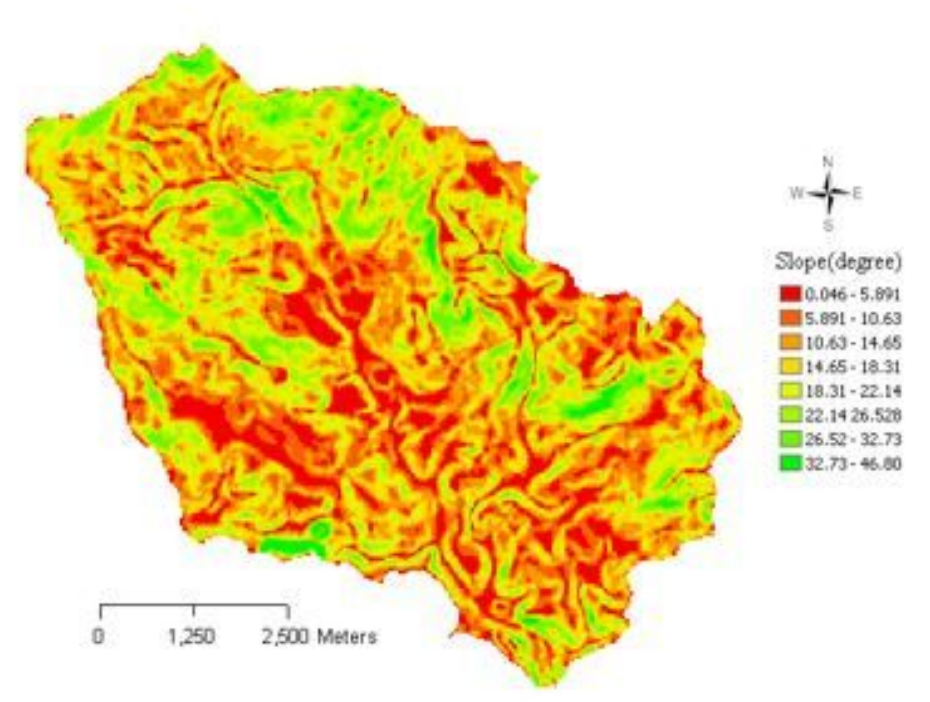

(d)

Figure 5

(a) DEM, (b) Flow Direction, (c) Contributing area, (d) Slope map of Coonoor watershed 


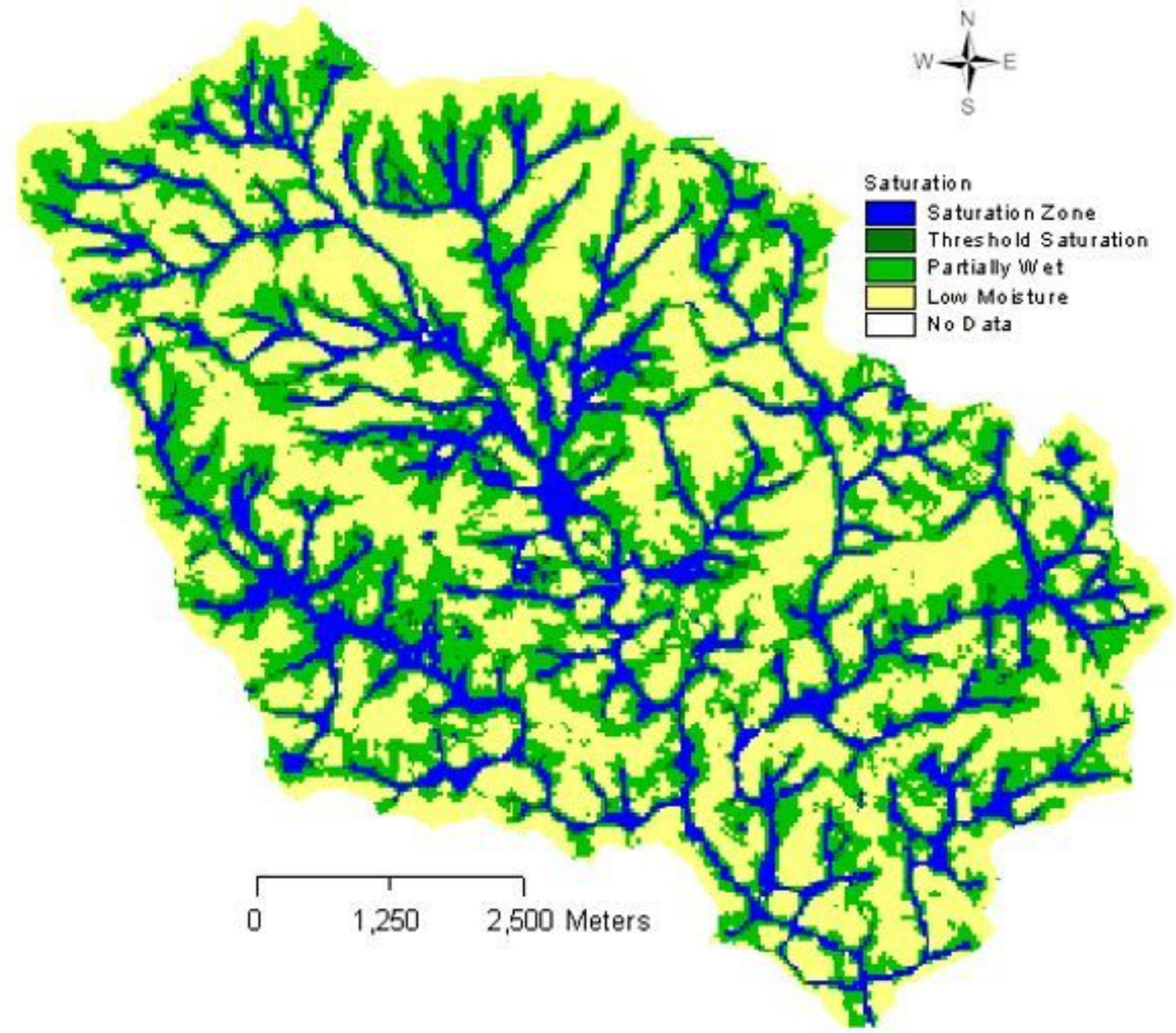

Figure 6

Saturation index map of Coonoor watershed 


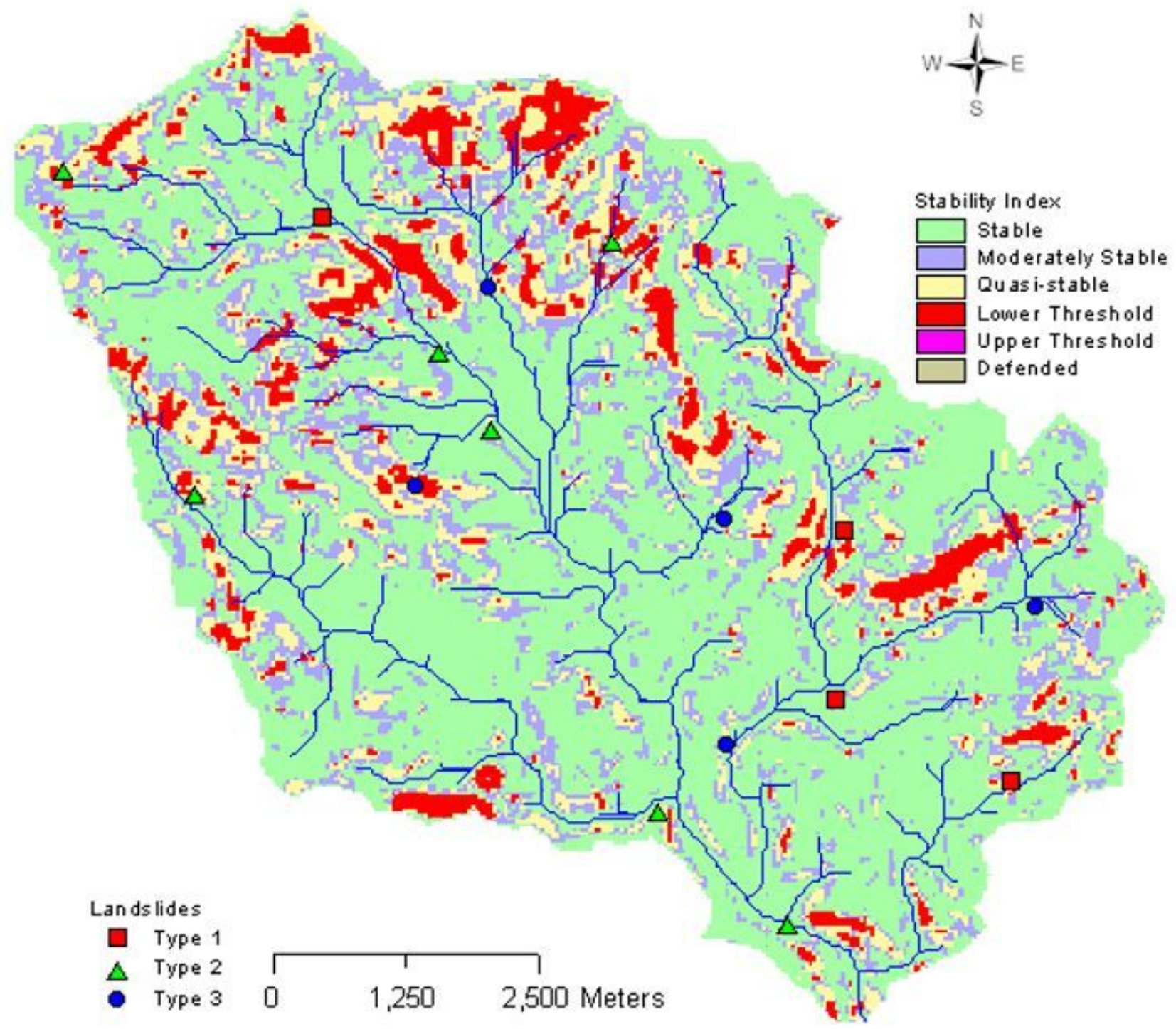

Figure 7

Stability index map of Coonoor watershed 


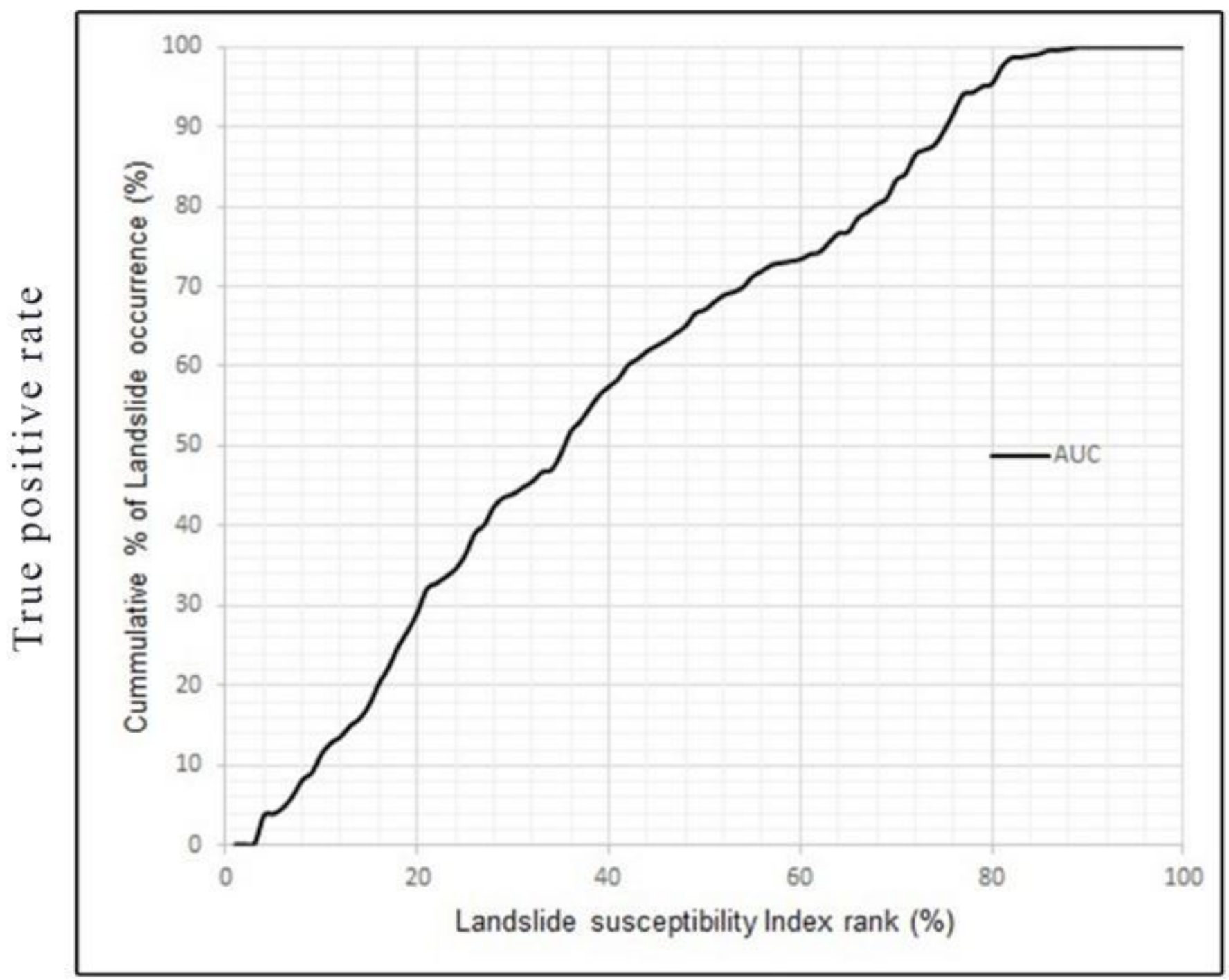

False positive rate

Figure 8

Receiver Operating Characteristic Curve 